\author{
УДК 32:316.614 \\ https://doi.org/10.34142/24130060.2019.17.1.04
}

\title{
МОДА І ПОЛІТИЧНА СОЦІАЛІЗАЦІЯ У СУЧАСНОМУ СУСПІЛЬСТВІ: ОСНОВНІ НАПРЯМИ ВЗАЄМОДІЇ
}

\author{
А.І. Воронкова \\ Харківський національний педагогічний університет імені Г.С. Сковороди \\ У статті висвітлено зміст провідних конщепцій політичної соціалізації у \\ сучасному науковому дискурсі. Також зроблено спробу проаналізувати основні напрями \\ впливу моди на політичну сочіалізацію за умов розвитку сучасного суспільства. Виявлено, \\ що мода здатна (у певному обсязі) впливати на всі змістовні та структурні складові \\ иььго комплексного багаторівневого процесу, але за сучасних умов розвитку суспільства \\ найбільш вагомо модні тендениії проявляються саме у двох провідних аспектах \\ здійснення політичної соціалізації: у формуванні політичної свідомості та у змінах \\ варіантів індивідуальної та колективної політичної поведінки. \\ Ключові слова: соціалізація, політична соціалізація, мода.

\section{МОДА И ПОЛИТИЧЕСКАЯ СОЦИАЛИЗАЦИЯ В СОВРЕМЕННОМ ОБЩЕСТВЕ: ОСНОВНЫЕ НАПРАВЛЕНИЯ ВЗАИМОДЕЙСТВИЯ}

\section{А.И. Воронкова}

В статье изложено содержание ведущчих концепџий политической социализаџии 8 современном научном дискурсе. Также сделана попытка проанализировать основные направления влияния моды на политическую сочииалиацию в условиях развития современного общества. Обнаружено, что мода способна (в определенном объеме) влиять на все содержательные и структурные составляющие этого комплексного многоуровневого процесса, но в современных условиях развития общества наиболее весомо модные тенденции проявляются именно в двух ведущцих аспектах осуществления политической социализации: в формировании политического сознания и в изменениях вариантов индивидуального и коллективного политического поведения.

Ключевые слова: социилизация, политическая соччиализация, мода.

\section{FASHION AND POLITICAL SOCIALIZATION IN MODERN SOCIETY: MAIN WAYS OF INTERACTION}

\section{A. Voronkova}

Progressive concepts of the political socialization in the modern scientific discourse are viewed in the article.

Firstly, some concrete attempts have been made to analyze basic ways of the influence of fashion on the political socialization in the conditions of the development of the modern society.

Within the framework it has been stated that the political socialization is a process which is featured by systematic nature. In other words, one change influences on other elements that all

(C) A.I. Воронкова, 2019 
together form one unique complex (it can be either a subject of the political socialization's realization or one of factors that changes the process of its realization).

Secondly, it has been assumed that fashion as a phenomenon of the social and political reality also has systematic nature. Consequently, if a change in one of its forms occurs it will provoke some «movements» in its «body». The main point about its development is the confrontation of opposite systematic patterns: the consolidation of the existing hierarchy of relationships and the change of already formed structural and status positions. Fashion does not exist off the area of its functioning and the surrounding, indeed, it needs to be in them, to be their common point. Moreover, relationships between fashion and the surrounding also have systematic nature.

In addition, it should be noticed that fashion as a systematic phenomenon influences on progressive processes in all subsystems of the social life. The political socialization is not an exception. For to concretize, the notion is one of the basic processes of the political sphere's functioning and happens when a person deals with the social political system in the context of his or her transformation into an individual, a citizen.

In conclusion, we should precise that in particular volume fashion influences on all main and structural components of this complex and multilevel process, but due to actual conditions of the development of the society the most valuable trends of the realization of the political socialization are considered to be the formation of the political consciousness and changes in variants of individual and collective political behavior.

Key words: socialization, political socialization, fashion.

Постановка проблеми. Політична соціалізація особистості - це процес iii адаптації до існуючої у суспільстві політичної системи та подальшого становлення в контексті перетворення iї на активного члена соціуму. Зрозуміло, що соціально-політичні трансформації, які спостерігаються в сучасному українському суспільстві в напрямку його подальшої демократизації, потребують нового рівня усвідомлення та здійснення процесу політичної соціалізації на всіх їі рівнях та напрямах.

Аналіз актуальних досліджень. Поняття політичної соціалізації запровадив у вжиток у 1959 американський дослідник Г. Хаймен (Левенець ред., 2011).

Вчені виділяють три основні стадії становлення сучасної теорії політичної соціалізації:

-1950-60 роки, становлення відбувалось у межах біхевіористської парадигми, «процес політичної соціалізації інтерпретувався як вплив політичного середовища на особистість шляхом передачі визначених моделей поведінки через систему організованих суспільних інститутів i цінностей». У цей час існувало уявлення, згідно з яким вважалося, що дитячі 
та юнацькі уявлення про політику залишаються незмінними протягом усього життя, і уявлення сформовані в більш ранньому віці надалі будуть чинити вагоміший вплив;

-1970-80 роки, «процес політичної соціалізації розглядався як «вертикальна» передача системи цінностей і моделей сприйняття політичної реальності від політичного режиму до особистості». Було виявлено, що вплив родини на політичну соціалізацію не є визначальним, також важливими $\epsilon$ вплив школи, однолітків, медіа і політичних подій;

- 3 середини 1980-х років, ця стадія «пов'язується 3 процесами політико-економічної та соціокультурної трансформації в країнах колишнього соціалістичного табору». Припускають, що все ж таки сім’я відіграє деяку роль в процесі політичної соціалізації (зокрема, суворе виховання формує консервативні погляди). Спираються на те, що політична соціалізація відбувається протягом усього життя і «політичні орієнтації людей відбивають той період соціалізації, що переживає людина в даний момент, займаючи визначену позицію в соціумі і політичній системі, членом якої є» (Вегеш ред., 2008).

В Україні проблеми політичної соціалізації вивчали та сьогодні продовжують досліджувати

В. О. Васютинський,

О. Т. Баришполець, М. Н. Корнєв, М. І. Пірен, М. М. Слюсаревський, В. О. Татенко, В. М. Фомичова та ін. Предметом дослідження цих науковців є зміст процесу політичної соціалізації, етапи та механізми ii здійснення, агенти та умови іiі ефективного існування в сучасному суспільстві тощо. Питання визначення місця та ролі моди в процесі політичної соціалізації, нажаль, ще не стало предметом особливої уваги представників системи соціально-політичного знання.

Відтак, метою статті є спроба визначення основних напрямів взаємодії моди та політичної соціалізації за умов розвитку сучасного суспільства.

Виклад основного матеріалу. У сучасному науковому дискурсі не існує загальноприйнятого визначення процесу політичної соціалізації. 
Наприклад, у політичній енциклопедії (2011 р.) цей процес визначається як «процес засвоєння індивідом ідеологічних і політичних цінностей, норм суспільства та формування їх у систему політичних ставлень, яка визначає найважливіші параметри взаємодії людини 3 політичною системою. Політична соціалізація - двосторонній процес: 3 одного боку, - це адаптація та інтеграція людини в суспільство через засвоєння нею політичного досвіду, цінностей, норм, настанов, притаманних суспільству в цілому, 3 іншого - реалізація прагнення особистості до розвитку незалежності, свободи та відстоювання власної позиції через вплив на політичні процеси» (Левенець ред., 2011).

У дослідженнях О.І. Романюка (ред., 2001, с. 521) підкреслюється, що у «політично організованих суспільствах людина завжди свідомо або несвідомо включена в систему політичних відносин, є носієм політичної культури», i, відтак, політичну соціалізацію пропонується розглядати як «перманентний процес включення людини в політичну систему, формування у неї певного ставлення до влади і політичної активності на основі засвоєння змісту політичної культури суспільства і самостійного осмислення сутності соціального буття».

До групи ідей, що становлять зміст провідних концепцій політичної соціалізації та не викликають більш-менш жорстких дискусій у сучасному науковому дискурсі, можна віднести такі твердження:

- поняття «політична соціалізація» більш широке, ніж поняття «політичне формування особистості», «політичне виховання», «політична освіта» та «політичне просвітництво»;

- політична соціалізація особистості - це певна взаємодія індивіда 3 політичною системою суспільства в контексті перетворення його на особистість громадянина;

- політична соціалізація - складний процес формування особистості громадянина, котрому притаманна певна послідовність: 
1) засвоєння й сприйняття суспільно-політичного досвіду, накопиченого попередніми поколіннями, а також сучасного досвіду;

2) перетворення знань про суспільство, політику держави у внутрішні переконання;

3) вироблення здатності відстоювати свої політичні погляди й інтереси;

4) набуття необхідних навичок суспільно-політичної діяльності, засвоєння нею основних принципів і норм;

5) реалізація знань і переконань у практичній політичній діяльності та в інших сферах суспільних відносин;

- цей процес передбачає одночасне існування: цілеспрямованого впливу на індивіда з боку пануючої політико-ідеологічної системи (через різноманітні політичні інститути та процеси); стихійного (так званого «позасистемного») впливу на індивіда 3 боку інших систем (через різні неполітичні структури та чинники); певного рівня впливу з боку самого індивіда на оточуючий його політичний світ (через різні види соціальної активності) $з$ метою його опанування;

- взаємодія особистості 3 політичною системою здійснюється в контексті виникнення двох процесів, кожен із яких постійно доповнює інший:

а) один із цих процесів - процес самовідтворення політичної системи завдяки механізму рекрутування, збереження та передачі своїх політичних цінностей, цілей і традицій новому члену суспільства;

б) другий - процес перетворення особистості в громадянина через формування іiі політичної свідомості та політичної поведінки в контексті функціонування певних вимог існуючої політичної системи (ii цінностей, норм, правил і зразків поведінки);

- політична соціалізація особистості - постійний безперервний процес;

- ця безперервність грунтується на постійній взаємній адаптації політичної системи та особистості; 
- політична соціалізація особистості як процес містить декілька головних стадій (етапів) або рівнів;

- найчастіше ця періодизація грунтується на вікових показниках життєвого шляху індивіда;

- існує два загальновизнаних етапи / рівні політичної соціалізації - етап / рівень первинної соціалізації та етап / рівень вторинної соціалізації):

етап первинної соціалізації становить період від народження індивіду до його трансформації у повноправного суб'єкта політичного процесу й найчастіше пов'язаний 3 процесом засвоєння ним вимог існуючої в суспільстві політичної культури;

етап вторинної соціалізації спостерігається у індивідів, які досягли середнього віку та активно діють у різних сферах (насамперед, в політичній) функціонування сучасного суспільства, й пов’язаний 3 процесом їхнього критичного переосмислення накопичених політичних знань / умінь та формуванням у них фундаментальних політичних орієнтацій та стійких моделей рольової поведінки;

- механізми політичної соціалізації функціонують на трьох рівнях системному (загально-соціальному), груповому (соціально-психологічному) та індивідуальному (внутрішньо-особистісному):

- перший рівень передбачає залучення індивіда до світу політики у межах всієї політичної системи суспільства (в контексті існування певних історичних, соціально-економічних, духовно-культурних, національних, релігійних умов його функціонування);

- другий рівень забезпечує входження індивіда в політичну сферу в контексті існування певних малих груп з конкретними системами політичних інтересів і цінностей, які формують саме його життєвий простір;

- третій рівень орієнтується на адаптацію індивіда до політичного життя в контексті взаємодії його когнітивних структур із системою цінностей та установок, які управляють поведінкою та усвідомленням особистості в політичній сфері; 
- адаптація індивіда до політичної сфери суспільства відбувається під впливом систем політичних і неполітичних факторів:

система політичних факторів представлена формою державного устрою, типом здійснення політичної влади, типом політичної системи, політичними інститутами, партіями, організаціями i рухами, що функціонують у даному суспільстві;

система неполітичних факторів включає як основні соціальні інститути - релігію, освіту, сім’ю, засоби масової інформації, так і інші елементи неполітичних сфер сучасного суспільства (Ольшанський, 2001; Резнік, 2003; Сазонов ред., 2001; Шестопал, 1988).

Виходячи iз вищезазначеного, можна стверджувати, що політична соціалізація є процесом, що має системний характер, тобто, зміни у будь-якій iii складовій (від суб'єкта організації до одного із факторів впливу на процес їі здійснення) викликають трансформацію в інших елементах, які становлять піi цілісність.

Мода як феномен соціально-політичної реальності також має системний характер. Тобто, зміни будь-якої 3 iï форм або складових викликають певні трансформації в усій іiі структурі. Визначальним моментом в іï розвитку виступає боротьба двох зустрічних системних тенденцій закріплення існуючої в суспільстві ієрархії відносин, і зміна сформованих в соціумі структурних і статусних позицій. Мода не існує ізольовано від простору свого функціонування та навколишнього середовища i зв'язку 3 ним. Останнє теж має системну природу.

Мода виникає не тільки в просторі виробництва одягу і прикрас, вона проявляється у всіх інших підсистемах суспільного життя: релігійній, науковій, правовій, моральній, мистецтвознавчій, спортивній, економічній, політичній та ін. Виходячи 3 особливостей сучасного етапу в розвитку суспільства i специфіки внутрішнього розвитку моди як системного утворення, пропонується розглядати ऑï як специфічну складову системи неполітичних факторів адаптації індивіда до політичної сфери суспільства. 
Тобто, мода впливає на процес формування політичної соціалізації індивіда не безпосередньо, а опосередковано через ії інші чинники та агентів, таких як: сім'я, найближче оточення, освітні заклади, церква, громадські організації, політичні партії та ін. Вона взаємодіє й, відповідно, трансформує усі сфери суспільного життя, в тому числі і перелічені. Зазнають змін, пов'язаних 3 модою, навіть найбільш стабільні соціальні інститути (трансформується навіть сім'я, в якій індивід проходить первинну соціалізацію).

Так, у контексті виникнення певних модних тенденцій, з одного боку, традиційні агенти соціалізації змінюють свої форми діяльності, а $з$ іншого 3'являються нові агенти соціалізації з новими напрямами та засобами впливу на свідомість та поведінку громадян з метою формування у них відповідного рівня політичної культури.

Аналіз існуючих світових практик щодо процесу взаємодії індивіда 3 політичною системою суспільства в контексті перетворення його на особистість громадянина свідчить, що найбільш вагомо модні тенденції проявляються в таких напрямах здійснення політичної соціалізації:

- вплив на політичну свідомість (насамперед, через презентацію «модних» джерел інформації);

- формування нових зразків політичної поведінки (зокрема, протестних, викликаних акцентом уваги на так званих «модних проблемах»);

- конструювання нового зовнішнього вигляду пересічного громадянина (з позиції урахування «модних» трендів на зачіски, одяг та певні аксесуари).

Ці процеси можна, насамперед, відстежити на результатах функціонування нових агентів соціалізації - Інтернет-ресурсах.

Так, мода на формування у Інтернет-мережі на сучасному етапі розвитку суспільства, зокрема українського, нових «ютуб-каналів» 3 політичною тематикою, які мають величезну кількість постійних глядачів, перетворює перші на ефективний засіб впливу на політичні переконання останніх. За допомогою «репостів» інформація тиражується їх 
прихильниками і таким чином ще більше поширює свій вплив на населення. Політична активність, у вигляді модних «флешмобів», з онлайну переходить у мітинги на вулиці. А яскравий імідж політичного лідера в соціальних мережах швидко перетворюється на «меми».

Вплив моди на процес політичної соціалізації у сучасному суспільстві наприкінці XX - початку XXI століття яскраво проявляється й у нових формах індивідуальної та колективної поведінки, зокрема, протестної. Тобто, у суспільстві постійно виникають i поширюються різні акції незгоди (насамперед, через Інтернет-ресурси) що викликані акцентом уваги на так званих «модних проблемах» - зокрема, щодо прав сексуальних і гендерних меншостей, підтримки здорового способу життя, проблеми харасменту і ін. У результаті з'являються Рух за права сексуальних і гендерних меншостей, Рух за сексуальну свободу, Рух «Життя без наркотиків», Рух за екологічно чисту їжу, Pух Time's Up і т. ін. (Воронкова, 2018b, с. 40-46).

Крім того, (як це було зазначено вище) у сучасному суспільстві модні тенденції істотно впливають й на конструювання нового зовнішнього вигляду пересічного громадянина (знов таки ж, насамперед, завдяки розвитку Інтернет-ресурсів). Мова йде про зачіски, одяг (святковий, робочий, спортивний тощо) та різні атрибути й аксесуари повсякденного життя.

У підгрунті здійснення цього процесу знаходиться механізм розповсюдження різних видів символів (зокрема, політичних).

Відповідно до тверджень вітчизняного дослідника С. Богатчука, «різноманітні символи мають велике значення в житті людей». I далі - «з допомогою символів вони взаємодіють одне з одним, і в цьому плані символи є певними засобами регулювання соціальної поведінки. Це визначається насамперед тим, що будь-яка інформація, що сприймається суб'єктом, є певною сукупністю візуальних i звукових символів. I кожен суб'єкт розшифровує їі зміст у формулах, що мають для нього певний сенс. Кожен народ опановує власні національно-державні символи, які створюються упродовж тривалого часу та базуються на давніх традиціях» (2004). 
Загальновідомо, що вперше політична символіка з’явилася на одязі в 1952 році в США - команда Дуайта Ейзенхауера створила цілу лінію, так званого, «політичного» одягу. На елегантному одязі (сукнях і блузах), а також на аксесуарах (окулярах i капелюхах), було написано «I like Ike» («Мені подобається Айк»), це був головний передвиборчий лозунг Д. Ейзенхауера, якого так називали близькі родичі в дитинстві, а пізніше (після перемоги на виборах) і всі в країні (Воронкова, 2018а).

Сьогодні мода на різні види політичної символіки (мовні, національно-державні, образотворчо-мистецькі політичні символи, політична емблематика, неполітичні символи, що набувають політичного змісту, люди, як політичні символи тощо) проявляється у всіх елементах зовнішнього вигляду та формах життя кожного члена суспільства. За висновками С. Богатчука, «політичні символи стають у суспільному житті певними образами найважливіших політичних ідеалів, важливими засобами їх пропаганди й реалізації, свідчать про ставлення до певної політичної позиції» (2004).

При цьому слід пам’ ятати, що:

по-перше, особливого значення та дієвості символи набувають під час політичних акцій, передвиборних кампаній, референдумів;

по-друге, навіть за умов ігнорування або прояву певного спротиву розповсюдження модним трендам на політичну символіку виникає ситуація, що підтверджує саме існування впливу перших на всіх представників сучасного соціуму.

У якості прикладів до цих тверджень можна навести такі. Герб є головним символом країни, через який, в тому числі, відбувається процес політичної соціалізації. У початковій школі дитина починає асоціювати різні держави з їх гербами (наприклад, білий орел на червоному фоні з Польщею, чорний орел з червоними лапами з Німеччиною, тризуб з Україною тощо).

Під час Революції Гідності популярними серед населення стали саме футболки з зображенням національного герба України, їх можна було 
побачити на вулицях столиці та інших українських міст. Люди, що носили ці футболки таким чином проявляли свою національну ідентичність (зокрема, знаходячись за кордоном), за допомогою такого символу демонстрували свій інтерес до політичних подій які відбувались, і небайдужість до вектору розвитку країни.

У цей же період бренд українського одягу HEYDAY UKRAINE (що перекладається як «Розквітай, Україно»), розробив популярні сьогодні у країнах Свропи, Канаді та США футболки з зображенням українського гербу (у авторській інтерпретаціі). Дизайнери в своїх колекціях, здебільшого, використовують переосмислену народну вишивку, державні символи та різні написи (гасла) українською (Якимів, 2014). Головний мессидж цієї та аналогічних з нею фірм та компаній - «зараз модно бути українцем, носити вишиванку або футболку з зображенням герба і за межами держави».

Висновки і перспективи подальших досліджень. Мода як системне явище впливає на провідні процеси у всіх підсистемах суспільного життя. Не $\epsilon$ винятком i політична соціалізація - один 3 центральних процесів функціонування політичної сфери (тобто, певна взаємодія індивіда 3 політичною системою суспільства в контексті перетворення його на особистість громадянина).

Як свідчить світова політична практика, мода здатна (у певному обсязі) впливати на всі змістовні та структурні складові цього комплексного багаторівневого процесу, але за сучасних умов розвитку суспільства найбільш вагомо модні тенденції проявляються саме у двох провідних аспектах здійснення політичної соціалізації: у формуванні політичної свідомості та у змінах варіантів індивідуальної та колективної політичної поведінки.

Очевидно, що у подальших дослідженнях зазначених процесів, насамперед, всебічного розгляду потребують проблеми обгрунтування ступеня конструктивності / деструктивності для всіх рівнів та сфер суспільного життя (в першу чергу політичної) цього впливу. 


\section{ЛІТЕРАТУРА}

1. Богатчук, С.С., 2004. Політична символіка. [online] Доступно: http://www.rusnauka.com/11_EISN_2010/Politologia/64233.doc.htm [Дата звернення 01 січень 2019].

2. Воронкова, А.И., 2018а. Мода в современном обществе: системное измерение. Веснік Гродзенскага дзяржаўнага ӱніверсітэта імя Янкі Купаль. Серыя 5. Эканоміка. Сацьиллогія. Біялогія, [online] 8(1) Доступно: https://vesnik.grsu.by/s_n/pre_249_ru.pdf [Дата обращения 27 грудень 2018].

3. Воронкова, А.І., 2018b. Протести і мода в сучасному суспільстві: політологічний вимір. Науково-теоретичний альманах «Грані», 21(11), с. 40-46.

4. Вегеш, М.М. ред., 2008. Політологія: підручник. 3-тє вид. Київ: Знання.

5. Левенець, Ю. ред., 2011. Політична енциклопедія. [online] Київ: Парламентське видавництво

Доступно: http://shron1.chtyvo.org.ua/Levenets_Yurii/Politychna_entsyklopediia.pdf [Дата звернення 25 грудень 2018].

6. Ніколаєнко, Н.О. та Годован, Ю.В., 2016. Інноваційні інститути політичної соціалізації молоді в Україні. Вісник Донецького національного університету ім. Василя Стуса. Серія: Політичні науки, [online] 1, с. 111-115. Доступно: http://jvestnik-politology.donnu.edu.ua/article/view/3947/3980 [Дата звернення 19 грудень 2018].

7. Ольшанский, Д.В. 2001. Основы политической психологии: Учебное пособие для вузов. Екатеринбург: Деловая книга.

8. Резнік, О. 2003. Політична самоідентифікація особистості за умов становлення громадянського суспільства. К.: Інститут соціології НАН України.

9. Сазонов, М.І. ред., 2001. Политология. Учеб. пособие для вузов. Харьков: Фолио.

10. Шестопал, Е.Б. 1988. Личность и политика. Критический очерк современных западных конщепций политической соџиализаџии. Москва: Мысль.

11. Якимів, X. 2014. HEYDAY UKRAINE BRAND. [online] Доступно: https://uamodna.com/interview/heyday-ukraine-brand/ [Дата звернення 25 грудень 2018].

\section{Інформація про автора}

Воронкова Анастасія Ігорівна - здобувач кафедри політології, соціології і культурології Харківського національного педагогічного університету імені Г.С. Сковороди; e-mail: annvoronkova@ukr.net; ORCID: https://orcid.org/0000-0001-7533-2999.

Стаття надійшла до редакції: 03.01.2019 p. $\quad$ Прийнята до друку: 15.01.2019 p. 